\title{
Research Note: Assessing Household Service Losses with Joint Survival Probabilities
}

\author{
Victor A. Matheson and Robert A. Baade
}

December 2006

\begin{abstract}
COLLEGE OF THE HOLY CROSS, DEPARTMENT OF ECONOMICS
FACULTY RESEARCH SERIES, PAPER NO. 06-11*
\end{abstract}

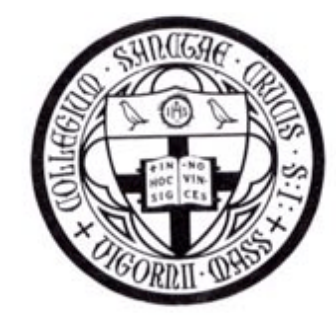

Department of Economics

College of the Holy Cross

Box 45A

Worcester, Massachusetts 01610

(508) 793-3362 (phone)

(508) 793-3708 (fax)

http://www.holycross.edu/departments/economics/website

*All papers in the Holy Cross Working Paper Series should be considered draft versions subject to future revision. Comments and suggestions are welcome. 


\title{
Research Note: Assessing Household Service Losses with Joint Survival Probabilities
}

\author{
Victor A. Matheson ${ }^{\dagger}$ \\ College of the Holy Cross \\ and \\ Robert A. Baade ${ }^{\dagger+}$ \\ Lake Forest College
}

December 2006

\begin{abstract}
Traditional analyses of household service losses in personal injury and wrongful death litigation calculate the losses over the expected lifetime of the injured or deceased individual. In fact, the losses to the surviving family members are more accurately described by using joint survival probabilities of the injured or deceased person and their survivors, or a "joint life expectancy.” The use of joint probabilities will always serve to reduce expected household service losses and these reductions can be especially significant when the deceased is significantly younger than the surviving spouse or if the survivor has a relatively low remaining life expectancy.
\end{abstract}

JEL Classification Codes: K13, K41

Keywords: forensic economics, household services

${ }^{\dagger}$ Victor A. Matheson, Department of Economics, Box 157A, College of the Holy Cross, Worcester, MA 01610-2395, 508-793-2649 (phone), 508-793-3708 (fax), vmatheso@holycross.edu

${ }^{\dagger+}$ Robert A. Baade, Department of Economics and Business, Lake Forest College, Lake Forest, IL 60045, 847-735-5136 (phone), 847-735-6193 (fax), baade@lfc.edu 


\section{Introduction}

The lost value of household services that a disabled or deceased household member used to perform is often included in damage claims in personal injury or wrongful death litigation. Indeed, in cases where the injured or deceased individual can show little evidence of labor force participation prior to the incident, or in cases where the affected party has only a short worklife expectancy after the accident, household services may represent a large portion of any damage settlement. Numerous scholarly papers have explored methods of estimating the monetary value of lost household services. Hicks, et al. (1991) provide an extensive, albeit at this point somewhat dated, bibliography of literature relevant to the valuation of household services. More recent studies include Dulaney, et al. (1992) and Tinari (1998; 2004).

All of these studies ignore a fundamental fact regarding household services, however. Unlike income, household services are much more difficult to transfer between individuals within an injured party’s estate. A parent, for example, can easily transfer a portion of their annual income to an adult child by simply writing a check. It is far more difficult for a parent to provide household services to the same adult child. Of course, parents often provide services such as child care to their adult children and may often provide other services such as semiregular cooking or cleaning, but this may be the exception rather than the rule.

This concept is at least implicitly understood by most forensic economists. Lost household services are rarely included in wrongful death cases where the deceased is a child or a single adult without dependents on the tacit assumption that these individuals' estates would not have been in a position to benefit from these household services had the person not died. Unless a single adult cared for dependents, any services produced by this person would have been 
consumed almost entirely by that individual rather than by parents or siblings of the deceased.

This paper presents a logical extension to this idea, applies it to the case of married individuals, and suggests that the use of joint survival probabilities is the appropriate method of assessing household service losses in wrongful death cases.

\section{Use of Joint Survival Probabilities}

As noted previously, the inclusion of lost household services is an important part of the calculation of damages in wrongful death and personal injury cases. The inclusion of household services is particularly compelling in cases where there is a strict division of household duties such that one spouse works in the labor market while the other spouse performs household work. If the spouse that performs the household role dies through negligence, it is clear that the surviving spouse should be entitled to monetary compensation even if the deceased spouse did not contribute a regular paycheck to the household. Lost household services are likely to exist in two-earner families as well, although the total losses from foregone household services are likely to be lower.

Typically lost household services are calculated over the entire expected lifespan of the deceased spouse unlike lost wages and benefits which are generally calculated only over an individual's expected worklife. It is not necessary in calculating lost wages and benefits due to wrongful death to account for the surviving spouse's life expectancy. A reasonable case can be made that the original wrongful death affects other members of the individual's estate besides the spouse by reducing any potential inheritance to surviving children or siblings. Generally, no such claim can be made regarding lost household services, however. Unlike a spouse, adult 
children or siblings of a person who dies through wrongful death are unlikely to have regularly received household services from the decedent even if they could reasonable expect a monetary inheritance. ${ }^{1}$ Household services, therefore, should be compensable only as long as both the deceased and the spouse were expected to have lived and not simply how long the deceased was expected to live. Of course, if minor children are also involved, the correct compensation also includes the length of time any children would be expected to live at home. The following examples will illustrate the effect that the use of joint probabilities has under several various scenarios.

Several simplifying assumptions will be made for ease of explanation. It is assumed that the loss of a spouse, regardless of gender, results in the annual loss of a constant $\$ 10,000$ in household services, and a zero percent real discount rate will be applied. All couples will be assumed to have no minor children and life survival probabilities for the general population (for each gender) are used in calculating survival probabilities and household service losses. Seven wrongful death scenarios will be examined. The first scenario will assume the wrongful death of a 40 -year old wife whose spouse is also 40 . Scenario two will involve the death of a 40 -year old husband survived by a 40-year old wife. Scenario three assumes the death of a 60-year old husband married to a 60-year old wife while scenario four assumes the opposite case. Scenarios five and six assume the death of a 40-year old wife married to a 60-year old husband and the

${ }^{1}$ Tinari (1998) argues that “two important services...a) companionship services and b) advice, guidance and counsel services, both of which are typically ignored in descriptions and listings of household services, should be included in order to obtain a more accurate and comprehensive measurement of the loss of nonmarket activities to surviving family members.” If this expansive definition of household services is accepted, then family members other than the surviving spouse or minor children may reasonably claim loss of household services from a wrongful death case. 
reverse. Scenario seven is an extreme case where a 26-year old wife is survived by an 89-year old husband. The ages in scenario seven are chosen because they clearly illustrate the pitfalls of simply using the deceased's life expectancy rather than the joint life expectancy of a married couple when calculating household services losses. The ages match those of former Playboy "Playmate of the Year” Anna Nicole Smith and her husband, oil billionaire J. Howard Marshall, at the time of their infamous marriage.

Lost household services will be calculated using two methods. Method 1 is the traditional method, based on the logic of the "life participation earnings (LPE) approach, that calculates the losses by multiplying the survival probability of the deceased for every year until age 100 (the age at which survival data is no longer published by the National Center for Health Statistics) by the lost annual household services for each year, and then discounting each result back to present value. Under the simplifying assumptions of a constant annual household service loss and a zero percent real discount rate, method 1 results in total household service losses of $\$ 10,000$ multiplied by the estimated life expectancy of the deceased individual.

Method 2 calculates lost household services using a joint survival probability. This method is identical to method one except instead of using the survival probability for the deceased, one uses the joint survival probability for the couple. The joint survival probability, in theory, is the probability that the deceased would have survived but for the wrongful death and the probability that the surviving spouse would have lived to enjoy the household services that are now lost. In practice, the joint survival probability is simply the product of the survival probability of the deceased and the survival probability of the surviving spouse. The sum of these joint survival probabilities over the entire possible lifetimes of the couple can be thought of 
as a "joint life expectancy" and is the expected time until the first spouse dies. As with method 1 , under the simplifying assumptions of a constant annual household service loss and a zero percent real discount rate, method 2 results in total household service losses of $\$ 10,000$ multiplied by the estimated joint life expectancy of couple. Table 1 shows the individual life expectancies, joint life expectancies, and total estimated household service losses under methods 1 and 2 for the 7 scenarios described previously.

As can be seen in Table 1, the use of joint probabilities serves to reduce household service losses, potentially by a significant amount. The reductions are larger (in percentage terms) when the deceased is female (due to the longer life expectancies of women) and if the couple is older. In addition, the reductions are also larger if the deceased is significantly younger than the survivor since in this case the survivor would have stood a large chance of dying before the younger spouse.

The hypothetical Anna Nicole Smith case presents the reasoning quite clearly. Had Ms. Smith died immediately after her marriage to Mr. Marshall, and had Mr. Marshall been able to provide evidence that Ms. Smith provided the assumed $\$ 10,000$ per year in household services, the traditional method of calculating losses would have compensated Mr. Marshall in the amount of $\$ 555$ thousand (assuming a zero percent real discount rate) since Ms. Smith’s life expectancy at the time of her assumed death would have been 55.5 years. However, in reality, Mr. Marshall, due to his advanced age, could only reasonably expect to have received these services for the remaining 5.1 years of his life expectancy (less a tiny fraction in the unlikely event that Ms. Smith died in some other fashion before Mr. Marshall's death). Ms. Smith would have been unlikely to provide Mr. Marshall's own adult children with household services, so the loss is 
more accurately characterized as a $\$ 51$ thousand loss, a reduction of over 90 percent compared with the traditional method.

The use of positive real discount rates reduces total losses under both method 1 and method 2; however, the higher the real discount rate, the smaller the difference between method 1 and method 2 becomes. For example, under scenario 5 where a 40 -year old wife is survived by a 60-year old husband, the use of a 3\% real discount rate for household services reduces losses under the traditional method to $\$ 230$ thousand and to $\$ 141$ thousand under the joint survival probability method. The joint probability method now results in a 38.4 percent reduction in estimated losses compared to the traditional method while the reduction was 52.4 percent when a zero percent discount rate was used.

\section{Conclusions}

Traditional analyses of household service losses calculate the losses over the expected lifetime of the deceased individual. In fact, the losses to the surviving family members are more accurately described by using joint survival probabilities of the injured or deceased person and their survivors, or a "joint life expectancy." The use of joint probabilities will always serve to reduce expected household service losses and these reductions can be especially significant when the deceased is significantly younger than the surviving spouse or if the survivor has a relatively low life expectancy. 


\section{References}

Dulaney, Ronald A., John H. Fitzgerald, Matthew S. Swenson and John H. Wicks (1992)

“Market Valuation of Household Production,” Journal of Forensic Economics, 5:2, pp. 115-126.

Hicks, Whitney W., Thomas R. Ireland, Edward J. Metzen and John O. Ward (1991) “Literature Relevant to the Valuation of Household Services (Bibliography),” Journal of Forensic Economics, 4:3, pp. 339-353.

Tinari, Frank D. (1998) “Household Services: Toward a More Comprehensive Measure,” Journal of Forensic Economics, 11:3, pp. 253-265.

Tinari, Frank D. (2004) “A Note on “Household Services: Toward a More Comprehensive Measurement,” Journal of Forensic Economics, 17:3, pp. 383-386. 
Table 1: Comparisons of Household Service Losses

\begin{tabular}{|l|l|l|l|l|l|l|l|l|l|}
\hline Scenario & $\begin{array}{l}\text { Age } \\
(\mathrm{W})\end{array}$ & $\begin{array}{l}\text { Age } \\
(\mathrm{H})\end{array}$ & Victim & $\begin{array}{l}\text { Life Exp. } \\
\text { Wife }\end{array}$ & $\begin{array}{l}\text { Life Exp. } \\
\text { Husband }\end{array}$ & $\begin{array}{l}\text { Life Exp. } \\
\text { Joint }\end{array}$ & $\begin{array}{l}\text { Damages } \\
\text { Method 1 }\end{array}$ & $\begin{array}{l}\text { Damages } \\
\text { Method 2 }\end{array}$ & Difference \\
\hline 1 & 40 & 40 & Wife & 42.0 & 37.4 & 32.6 & $\$ 420 \mathrm{~K}$ & $\$ 326 \mathrm{~K}$ & $-22.4 \%$ \\
\hline 2 & 40 & 40 & Husband & 42.0 & 37.4 & 32.6 & $\$ 374 \mathrm{~K}$ & $\$ 326 \mathrm{~K}$ & $-12.8 \%$ \\
\hline 3 & 60 & 60 & Wife & 24.2 & 20.9 & 16.8 & $\$ 242 \mathrm{~K}$ & $\$ 168 \mathrm{~K}$ & $-30.6 \%$ \\
\hline 4 & 60 & 60 & Husband & 24.2 & 20.9 & 16.8 & $\$ 209 \mathrm{~K}$ & $\$ 168 \mathrm{~K}$ & $-19.6 \%$ \\
\hline 5 & 40 & 60 & Wife & 42.0 & 20.9 & 20.0 & $\$ 420 \mathrm{~K}$ & $\$ 200 \mathrm{~K}$ & $-52.4 \%$ \\
\hline 6 & 60 & 40 & Husband & 24.2 & 37.4 & 22.2 & $\$ 374 \mathrm{~K}$ & $\$ 222 \mathrm{~K}$ & $-40.6 \%$ \\
\hline 7 & 26 & 89 & Wife & 55.5 & 5.1 & 5.1 & $\$ 555 \mathrm{~K}$ & $\$ 51 \mathrm{~K}$ & $-90.8 \%$ \\
\hline
\end{tabular}

